\title{
Biophysical and socioeconomic factors explaining the extent of forest cover on private ownerships in a Midwestern (USA) agrarian landscape
}

\author{
E.A. Frimpong ${ }^{1}$, A.L. Ross-Davis ${ }^{1} *$, J.G. Lee ${ }^{2}$ and S.R. Broussard ${ }^{3}$ \\ ${ }^{1}$ Department of Forestry and Natural Resources, Purdue University, 715 West State Street, West Lafayette, \\ Indiana 47907-2061, USA; ${ }^{2}$ Department of Agricultural Economics, Purdue University, 403 West State \\ Street, West Lafayette, Indiana 47907-2056, USA; ${ }^{3}$ Department of Forestry and Natural Resources, Purdue \\ University, 195 Marsteller Street, West Lafayette, Indiana 47907-2033, USA; *Author for correspondence \\ (e-mail:arossdav@purdue.edu)
}

Received 15 August 2005; accepted in revised form 25 November 2005

Key words: Biophysical attributes, Conservation programs, Indiana, Landowner attributes, Midwest, Nonindustrial private forest, Private lands policy, USA, Variation partitioning

\begin{abstract}
As landscape fragmentation continues to escalate, it is imperative that we improve our understanding of the factors that contribute to the creation and retention of forest on privately-owned land to most effectively design and implement conservation policy. This article presents the percentages of variation in the proportion of forest on private ownerships across an agriculturally-dominated landscape in north-central Indiana, USA that can be explained by biophysical characteristics, landowner (socioeconomic) attributes, and private landowner assistance programs. While biophysical characteristics of the land accounted for the majority of variation explained $(17.35 \%, p<0.0001, n=194)$, attitudinal and demographic attributes of the landowners contributed significantly to explaining additional variation $(7.97 \%, p<0.0001)$, and overlapped with biophysical characteristics to explain another $17.31 \%$. Program familiarity and enrollment did not explain a significant amount of the variation independent of either biophysical or landowner attributes. Private landowner assistance programs should broaden their objectives and increase incentives to appeal to the variety of landowners who possess the decision-making authority for most of the land in the region and the nation as a whole.
\end{abstract}

\section{Introduction}

Does the amount of forest cover on privatelyowned land depend on features of the landscape, attributes of the landowners, or some combination of the two? What role do private landowner assistance programs play independent of landscape and landowner characteristics, if any? This research seeks to answer these questions through the use of Geographic Information Systems (GIS) and survey data collected from family forest owners in north-central Indiana, USA.

Almost half of the forestland in the US is owned by family forest owners (Butler and Leatherberry 2004). In the Midwestern states, nonfederal land ownership ranges from $89.5 \%$ in Minnesota to $99.2 \%$ in Kansas, with Indiana standing at $98.3 \%$ (Turner 1997). Most of this nonfederal ownership is nonindustrial private (Birch 1996). These private forests provide innumerable benefits to society 
including timber production, recreational opportunities, wildlife habitat, and water quality protection. In landscapes altered by anthropogenic uses such as agriculture and residential development, patches of forest act as refugia and may be the only sources of native populations for landscape restoration (Marsh and Luey 1982; Frissel and Bayles 1996). Globally, forests constitute a store of biodiversity and act as a sink for atmospheric carbon. Although most temperate North American forests were lost as a result of European settlement, in many parts of the American Midwest, forests have since regenerated as a result of agricultural abandonment (Medley 1995; Brown 2003).

Patterns of forest cover across the American landscape are changing, partly a reflection of changing tenure and increasing diversity of private forest owners' ownership motivations (e.g., Kendra and Hull 2005). Whether as relics of the past or having regenerated following agricultural abandonment, forest cover tends to be spatially coincident with agriculturally-inferior biophysical features such as steep slopes, shallow, course-textured soil, and poor drainage (Auclair 1976; Iverson 1988; Pan et al. 1998; Brown 2003; Scull and Harman 2004). Land-use changes are triggered by socioeconomic forces and are constrained by the underlying physical landscape structure (Iverson 1988; Pan et al. 1998). Socioeconomic forces may be regional (e.g., population growth, markets, taxes and subsidies, regulations) or micro-scale (landowner attributes and behavior). Whereas numerous studies have tied land-use and landcover change to regional-scale socioeconomic forces (e.g., Burgi and Turner 2002; Brown 2003), there is evidence to suggest that when considering a local watershed, micro-scale socioeconomic factors coupled with variation in the physical condition of the watershed may be more important than regional socioeconomics and governmental policies (Medley et al. 1995).

Ultimately, the decision to convert a patch of forest to cropland or vice versa is made at the parcel level by individual landowners and the regional view of the landscape is a reflection of the cumulative decisions of these individuals (Odum 1982). Erickson et al. (2002) reported that the strongest motivator for retaining forest cover on private lands in rural Michigan was aesthetic appreciation. They found that forests were developing along riparian corridors, at the edge of existing forests, and at the edges of agricultural fields, where drainage was poor. Thus, socioeconomic factors intersect with biophysical factors of the landscape to influence behavior and, ultimately, land cover. In addition to ownership motivations, a number of other landowner characteristics have been shown to influence land-use decisions such as farming status and income (Alig et al. 1990; Lönnstedt 1997; Beach et al. 2005), education and use of assistance programs (Royer and Moulton 1987; Alig et al. 1990; Zhang and Flick 2001; Beach et al. 2005), gender (Lidestav and Ekström 2000; Beach et al. 2005), age (Beach et al. 2005), and residency status (Loyland et al. 1995). Studies have also demonstrated relationships between environmentalism, which helps to define the context in which land-use decisions are made, and religiosity (Kanagy and Nelsen 1995) as well as political ideology and party affiliation (Van Liere and Dunlap 1980; Jones and Dunlap 1992; Guber 2003).

Several voluntary governmental (via both federal and state agencies, and often in partnership) and non-governmental programs aimed at watershed conservation are available to landowners to assist with technical (e.g., through development of management plans) and financial (e.g., through provision of cost-share funds) aspects of management (Best and Wayburn 2001). Many of these programs are products of Farm Bills, which are revised approximately every 6 years to reflect an evaluation of the programs and policies available through the United States Department of Agriculture (USDA). With so many land and landowner attributes interacting to determine whether land is farmed, developed, or kept in (or reverted to) forest, it is important to evaluate the role these programs play in the conservation of private forestland. To be successful, efforts to safeguard existing forest and to return some agricultural land to less intensive management must take advantage of and build upon the motivations of private landowners to be involved in conservation practices. As the landscape becomes more fragmented, parcelized, and owned by non-traditional rural residents [i.e., exurbanites who generally bring a preservationist orientation to ownership compared with the more utilitarian perspective of traditional rural residents (see Egan and Luloff 2000)], the need to understand factors that contribute to the 
creation and retention of forest on privatelyowned land is important to effective policy design and implementation. The objective of this study was to determine the independent and combined roles of biophysical land characteristics, landowner attributes, and familiarity with and enrollment in conservation programs in explaining the proportion of forest cover on privately-owned lands across the landscape of north-central Indiana, USA.

\section{Methods}

\section{Study area}

The study was conducted in the Wildcat, Little Vermillion, and Middle Wabash watersheds, which together stretch across $4852 \mathrm{~km}^{2}$ of northcentral Indiana, USA (Figure 1). The area, bounded geographically by $85^{\circ} 44^{\prime}-87^{\circ} 31^{\prime} \mathrm{W}$ longitude and $40^{\circ} 42^{\prime}-40^{\circ} 70^{\prime} \mathrm{N}$ latitude, is quite typical of the agricultural landscapes of the Midwestern USA. These watersheds are part of the Eastern and Central Corn Belt Plains ecoregions, two of the 120 ecological regions of the conterminous USA delineated based on patterns of geology, physiography, vegetation, climate, soils, land use, wildlife, and hydrology (Omernik 1987). Crop production (soybeans and corn) and grazing are the characteristic land uses for both ecoregions, and the land form is smooth plains. Based on the most recent

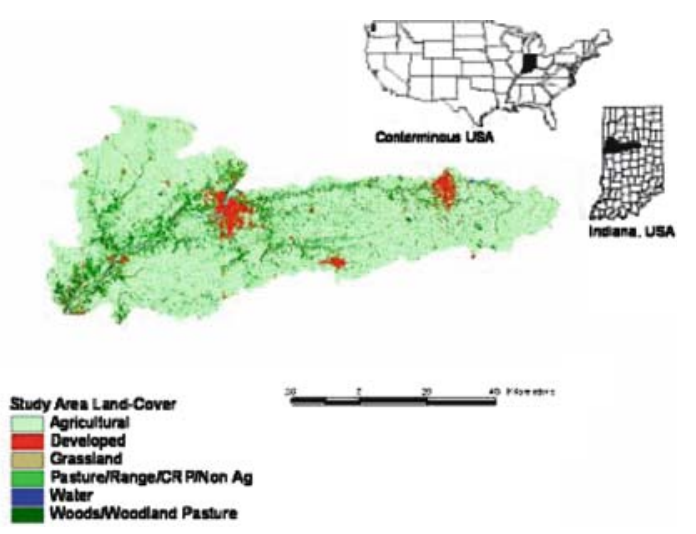

Figure 1. Map of study area in north-central Indiana, USA, showing the distribution of land-cover. edition of Thematic Mapper data for the region (USDA-National Agriculture Statistics Service (NASS) 2005) land-cover in the Wildcat, Little Vermillion, and Middle Wabash watersheds is $74.8 \%$ agriculture, $11.2 \%$ pasture/range/Conservation Reserve Program (CRP)/non agricultural vegetation, $7.8 \%$ woods (forest)/woodland pasture, $4.8 \%$ developed land, $1.1 \%$ grassland (including urban grasses), and $0.3 \%$ water. Based on State Soil Geographic (STATSGO; Natural Resources Conservation Service 1994) map unit classifications, $99 \%$ percent of the area is prime or conditionally prime agricultural land, including $35 \%$ prime, $58 \%$ prime if drained, and $6 \%$ prime if drained and prevented from flooding during the growing season. The natural forest vegetation of the Eastern Corn Belt Plains is beech-maple and that of the Central Corn Belt Plains is oak-hickory (Omernik 1987). Major soil and surficial deposit types found in the study area include thin or moderately thick loess over loamy glacial till and alluvial and outwash deposits (Franzmeier et al. 2001). From a demographic perspective, this region is characterized by modest population growth, which averaged $5.4 \%$ for the counties that fell within the study region and ranged from a $1.0 \%$ loss to $14.1 \%$ growth (compared to the state average of $9.7 \%$ and the national average of 13.2\%) (United States Census Bureau 2005). The median household income in 1999 was just below that of the nation (i.e., $\$ 41,094$ (ranging from $\$ 36,162$ to $\$ 48,546$ ) compared to the national estimate of \$41,994) (United States Census Bureau 2005).

\section{Sample}

The subset of parcels and corresponding landowners included in this study were selected through a stratified random sampling scheme (refer to Moore and Swihart 2005 for details of the stratification). Twelve $23 \mathrm{~km}^{2}$ sample sites were selected in total, four from each of the three sublandscape types (i.e., forested, agricultural, and mixed forest/agricultural). These 12 sites spanned seven counties (Figure 1). Addresses for all landowners who owned at least 0.4 ha $(1$ acre $)$ of forest cover in these sites were obtained from property tax records located at county assessors' offices, which were cross-referenced with the most recent 
aerial photographs for all sections within our sample area to confirm that parcels met the selection criterion.

\section{Survey}

A 12-page survey was pre-tested (via the Tailored Design Method; Dillman 2000) in a representative site from 25 September through 3 November 2003. Following revision, the final version of the survey was distributed over the course of 7 weeks from 6 February through 24 March 2004. Of the 737 surveys sent to landowners, 23 were undeliverable, 3 were sent to landowners who were deceased, 19 were sent to landowners who no longer owned forest, 12 landowners refused to complete the survey, and 348 were returned complete for a final response rate of $50.3 \%$. To examine potential nonresponse bias, a number of property features and tax variables were compared between respondents and nonrespondents. The only characteristic by which nonrespondents differed from respondents was the total acreage enrolled in the Classified Forest Program. Respondents had significantly more acreage enrolled in the Classified Forest Program than did nonrespondents. Of the 348 returned surveys, 194 were useable due to missing data in 154 cases.

\section{Determining parcel boundaries and land cover}

Using 1998 digital orthoquads for each sample region in combination with plat maps received from each county assessor's office, polygons of respondents' properties were created. Because several landowners owned more than one parcel in the study region, we dissolved parcels by landowner to create a 'single' parcel record in order to link the biophysical data to the survey data. Digitization and all subsequent analyses involving spatial data were conducted in ArcGIS 8.3/9.0 or ArcView 3.2 depending on convenience and availability of necessary tools and extensions. The proportion of parcels covered with forest was determined for each landowner based on Thematic Mapper land-cover data (NASS 2005). Land-cover categories were reclassified by combining those groups indicated in parentheses into the following classes: (1) agriculture (corn, soybeans, winter wheat, other small grains and hay, winter wheat/ soybeans double cropped, alfalfa, miscellaneous fruits and vegetables, mint, chick peas, other crops, and fallow idle cropland), (2) forest (woods/ woodland pasture, pasture/range/CRP/non agriculture), (3) developed land, (4) water, and (5) grassland. The 'pasture/range/CRP/non agriculture' cover type predominantly occurred at the margin of wooded riparian areas (Figure 1) and was judged to constitute land not intensively managed for crop production and, in most cases, reverting to forest. There were two major reasons for including the 'pasture/range/CRP/non agriculture' cover type in the forest cover class. Firstly, additional sources of information (aerial photos, tax records, and enrollment in landowner assistance programs) suggested that most of this vegetation class was recognized as forest. Thus, classifying only the 'woods/woodland pasture' as forest constituted an underestimation of forest in a way that introduced major inconsistencies in our data. Secondly, the occurrence of the 'pasture/ range/CRP/non agriculture' cover type primarily between wooded riparian areas and agricultural fields suggested that most of this class was agricultural land in various stages of reverting to forest. Since we were also interested in the biophysical characteristics of land that has been withdrawn from agricultural use (for example, as a result of program enrollment) it was more appropriate to overestimate than underestimate actual forest coverage. The response variable was created by dividing the forest class acreage by the total acreage less the acreage designated as developed, grassland, and water. Thus, forest was measured as the proportion of open space that remains as forest or other less intensively managed land (as opposed to agriculture).

\section{Biophysical Data Matrix}

Biophysical data included surficial geology (Indiana Geological Survey 2002a), depth of unconsolidated material (Indiana Geological Survey 2002b), floodplains (Bernardin et al. 2002), and slope derived from a $30 \mathrm{~m}$ digital elevation model (DEM; United States Geological Survey 2004). Each parcel was designated an underlying geology type based on majority (i.e., over $50 \%$ ). Because the depth of unconsolidated material was reported 
Table 1. Data format for biophysical variables.

\begin{tabular}{ll}
\hline Variable & Scale \\
\hline Slope (degree) & Continuous \\
Depth of unconsolidated material (meters) & Continuous \\
Drainage (well drained) & Binary $(1,0)$ \\
Drainage (poorly drained) & Binary $(1,0)$ \\
Surficial Geology (loam/drift) & Binary $(1,0)$ \\
Surficial Geology (alluvium/shale & Binary $(1,0)$ \\
Floodplain & Binary $(1,0)$ \\
Prime Farmland Status (prime) & Binary $(1,0)$ \\
Prime Farmland Status (not prime) & Binary $(1,0)$
\end{tabular}

${ }^{\mathrm{a}}$ A combination of several surface lithologic classes dominated by shale, but also including limestone, sandstone, siltstone, and coal.

as a $15 \mathrm{~m}$ (50 foot) range, the average depth per parcel was calculated based on an average calculated from the original ranges. The proportion of each parcel within a designated floodplain was calculated using zonal analysis in ArcGIS. Slope (in degrees) was derived from the DEM in ArcView using the surface tool and the average slope was calculated for each parcel using zonal analysis. Drainage and prime farmland status for each parcel were determined from the STATSGO database for Indiana (Natural Resources Conservation Service 1994). The biophysical data matrix consisted of continuous and binary variables (Table 1). Although more variability due to these biophysical factors could be explained by using data of higher resolution, the data used were of the best available resolution that covered the entire study area.

\section{Socioeconomic data matrix}

The socioeconomic data matrix comprised the following landowner characteristics: (1) age, (2) gender, (3) place of residence description (i.e., urban, suburban, or rural), (4) farming status (i.e., whether or not the respondent self-identified as a farmer), (5) political ideology, (6) educational attainment, (7) annual household income, (8) religiosity, (9) marital status, (10) tenure (i.e., length of land ownership), (11) total acreage owned, (12) resident status (i.e., whether the landowner resided on their land or was absentee), (13) a management index, and (14) ownership motivations (see next paragraph for details). The management index was created by summing the number of management activities in which the landowner had engaged in the past and ranged from 0 (if a given landowner had not planted trees beyond landscaping around their home, pre-commercially thinned (also referred to as a Timber Stand Improvement), or harvested trees from their land in the past) to 3 (if the landowner had done all three activities in the past).

To uncover latent ownership motivations from a total of 14 survey items used to operationalize various reasons landowners may have for owning forest, we used exploratory factor analysis by means of Principal Component Analysis. Four distinct subscales emerged from the analysis (with an overall reliability of $\alpha=0.842$ and accounting for $64.03 \%$ of the total variance in the data matrix). The subscales were named as follows: (i) lifestyle, (ii) consumption, (iii) conservation, and (iv) legacy and heritage (Table 2). Factor scores were calculated for each subscale using the regression method such that mean $=0$ (Norussis 2003). Due to missing values, the total sample size for this analysis was 220, out of which 194 constituted the final sample. The socioeconomic data matrix consisted of both continuous and binary variables (Table 3).

\section{Programs data matrix}

The programs data were based on landowners' familiarity with and participation in a variety of landowner assistance programs including (1) state tax abatement programs (Classified Forest and Wildlife Habitat Programs), (2) conservation Farm Bill programs (Conservation Reserve Program (CRP), Wetland Reserve Program (WRP), Forest Land Enhancement Program (FLEP), Wildlife Habitat Incentives Program (WHIP), Forestry Incentives Program (FIP), and Stewardship Incentive Program (SIP)), (3) forest certification organizations (Forest Stewardship Council (FSC), Sustainable Forestry Initiative (SFI), and American Tree Farm System), (4) conservation easements, and (5) land trusts. While not all of these programs and opportunities encourage afforestation, reforestation, or maintenance of existing forest cover exclusively, conservation of or conversion to forest cover is a component of each. The programs data matrix consisted of both continuous and binary variables (Table 4). 
Table 2. Rotated component matrix for 14-item conception of ownership motivations scale. ${ }^{\text {a }}$ Values are the factor loadings which are correlations between the original variables (i.e., items) and the factors.

\begin{tabular}{|c|c|c|c|c|}
\hline Items & Lifestyle & Consumption & Conservation & Legacy and Heritage \\
\hline To pass on to my children or other heirs & 0.151 & 0.144 & 0.109 & 0.896 \\
\hline As part of my family heritage & 0.033 & 0.103 & 0.072 & 0.903 \\
\hline To enjoy scenery & 0.604 & -0.001 & 0.357 & 0.292 \\
\hline As a long-term financial investment & 0.011 & 0.588 & 0.380 & 0.193 \\
\hline To collect firewood & 0.259 & 0.739 & -0.051 & -0.010 \\
\hline To pick nuts, berries, mushrooms, etc. & 0.573 & 0.510 & 0.069 & -0.013 \\
\hline To supply food and habitat for wildlife & 0.487 & -0.014 & 0.562 & -0.093 \\
\hline For privacy & 0.800 & 0.081 & 0.100 & 0.095 \\
\hline For timber production & -0.012 & 0.809 & 0.124 & 0.121 \\
\hline To have trees surrounding my primary or vacation home & 0.727 & 0.125 & 0.145 & -0.042 \\
\hline For hunting and fishing & 0.371 & 0.405 & 0.040 & 0.222 \\
\hline For recreation other than hunting and fishing & 0.588 & 0.269 & 0.359 & 0.227 \\
\hline To learn from nature & 0.365 & 0.098 & 0.778 & 0.107 \\
\hline To protect the watershed/provide clean water & 0.061 & 0.164 & 0.850 & 0.131 \\
\hline
\end{tabular}

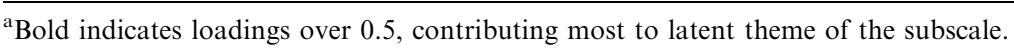

Table 3. Data format for socioeconomic variables.

\begin{tabular}{ll}
\hline Variable & Scale \\
\hline Acreage (hectares) & Continuous \\
Age (years) & Continuous \\
Tenure (years) & Continuous \\
Lifestyle (standardized factor score) & Continuous \\
Consumption (standardized factor score) & Continuous \\
Conservation (standardized factor score) & Continuous \\
Legacy and Heritage (standardized factor score) & Continuous \\
Gender & Binary $(1,0)$ \\
Farming Status (farmer/ not farmer) & Binary $(1,0)$ \\
Politically Liberal & Binary $(1,0)$ \\
Politically Conservative & Binary $(1,0)$ \\
Education (post secondary/no post-secondary) & Binary $(1,0)$ \\
Religiosity (attend services once per year or & Binary $(1,0)$ \\
less/several times per year or more) & \\
Income (above/below \$74,999) & Binary $(1,0)$ \\
Marital Status (married/not married) & Binary $(1,0)$ \\
Rural resident & Binary $(1,0)$ \\
Residency (does/does not reside on parcel) & Binary $(1,0)$ \\
Management (have/have not engaged in) & Binary $(1,0)$ \\
\hline
\end{tabular}

\section{Data analyses}

The biophysical (B), socioeconomic (S), and programs (P) data matrices were considered a complementary set of predictors that may be used to explain variation in the proportion of private parcels that maintain forest cover. As such, partial linear regression, which assumes that effects are additive, is an appropriate method to estimate how much of the variation in the response variable
Table 4. Data format for program familiarity (F) and enrollment (E) variables. ${ }^{a}$

\begin{tabular}{|c|c|}
\hline Variable & Scale \\
\hline Familiarity Index (number of programs) & Continuous \\
\hline Enrollment Index (number of programs) & Continuous \\
\hline Classified Forest Program - $(\mathrm{F})$ & Binary $(1,0)$ \\
\hline Wildlife Habitat Program - (F) & Binary $(1,0)$ \\
\hline Conservation Reserve Program - (F) & Binary $(1,0)$ \\
\hline Forestry Incentives Program - $(\mathrm{F})$ & Binary $(1,0)$ \\
\hline Stewardship Incentives Program - (F) & Binary $(1,0)$ \\
\hline Wetland Reserve Program - (F) & Binary $(1,0)$ \\
\hline Forest Land Enhancement Program $-(\mathrm{F})$ & Binary $(1,0)$ \\
\hline Wildlife Habitat Improvement Program - (F) & Binary $(1,0)$ \\
\hline Certification $-(\mathrm{F})$ & Binary $(1,0)$ \\
\hline Easement - (F) & Binary $(1,0)$ \\
\hline Land Trust $-(\mathrm{F})$ & Binary $(1,0)$ \\
\hline Classified Forest Program - (E) & Binary $(1,0)$ \\
\hline Wildlife Habitat Program - (E) & Binary $(1,0)$ \\
\hline Conservation Reserve Program - (E) & Binary $(1,0)$ \\
\hline Wetland Reserve Program - (E) & Binary $(1,0)$ \\
\hline Certification - (E) & Binary $(1,0)$ \\
\hline Easement - (E) & Binary $(1,0)$ \\
\hline Land Trust $-(\mathrm{E})$ & Binary $(1,0)$ \\
\hline
\end{tabular}

${ }^{a}$ Some programs did not have any respondents enrolled.

(measured as the adjusted- $R^{2}$ ) can be attributed exclusively to one set of explanatory variables once the effect of other sets of variables have been taken into account (Whittaker 1984; Lengendre and Lengendre 1998). The multivariate version of this method is often used to partition variation among spatial, environmental, and sometimes temporal 
components of species data sets (e.g., Anderson and Gribble 1998; Magalhaes et al. 2002). Because the biophysical variables used in this study are all inherently spatial, and three matrices had already been selected for investigation, incorporating an additional explanatory data set of spatial locations was deemed less beneficial compared to the added complexity it would contribute to the methodology and presentation.

Prior to computing regressions, all continuous explanatory variables were examined for normality. Transformations were deemed necessary for slope (square root $(x))$ and parcel acreage $(\log 10(x))$. Given the availability of software to compute multiple regressions, a series of steps that avoid explicit partial regression were used and are summarized here. The following five steps were followed to obtain various adjusted- $R^{2} \mathrm{~s}$ and sums of squares, which were then used to partition the variation by arithmetically solving for each component of a hypothetical Venn diagram.

(1) A multiple regression model of the proportion of forest cover against the biophysical explanatory data set was computed to obtain adjusted $R^{2}$ and model sum of squares representing the fraction $\mathrm{B}+\mathrm{BS}+\mathrm{BP}+\mathrm{BSP}$. A subset of variables was selected from the full suite of variables using the $\mathrm{Cp}$ and adjusted $R^{2}$ selection criteria (Mallow 1964; Neter et al. 1996). The Cp statistic is a measure of bias in a model, and the criterion seeks to minimize bias. Adjusted $R^{2}$ measures the proportion of variance in the response explained by the selected model, with a penalty for model complexity. Collinearity in models was controlled with the tolerance criterion (Neter et al. 1996). The specific criteria that had to be met for a model to be selected were that (i) $\mathrm{Cp}$ was smaller than or approximately equal to the number of parameters in the model, (ii) the model had the highest adjusted $R^{2}$ among candidate models, (iii) the global $F$-test for the model had $p<0.05$, and (iv) individual $t$ test for selected variables had $p<0.25$. The reduced model selected was computed and subjected to residual analysis to ensure a reasonable degree of homoscedasticity and normality of residuals. All analyses were conducted in $\mathrm{SAS}^{\circledR} 8.02$. The model development and evaluation procedures were repeated with the socioeconomic data to obtain the adjusted $R^{2}$ and model sum of squares for fraction
$\mathrm{S}+\mathrm{BS}+\mathrm{SP}+\mathrm{BSP}$, and with the programs data set to obtain the adjusted $R^{2}$ and model sum of squares for the fraction $\mathrm{P}+\mathrm{BP}+\mathrm{SP}+\mathrm{BSP}$. (2) A multiple regression model of proportion of forest cover against the subset of biophysical and socioeconomic variables selected in step 1 was computed to obtain adjusted $R^{2}$ and model sum of squares corresponding to the fraction $\mathrm{B}+\mathrm{S}+\mathrm{BS}+\mathrm{BP}+\mathrm{SP}+\mathrm{BSP}$.

(3) A multiple regression model of proportion of forest cover against the subset of biophysical and programs variables selected in step 1 was computed to obtain adjusted $R^{2}$ and model sum of squares corresponding to the fraction $\mathrm{B}+\mathrm{P}+\mathrm{BP}+\mathrm{BS}+\mathrm{SP}+\mathrm{BSP}$.

(4) A multiple regression model of proportion of forest cover against the subset of socioeconomic and programs variables selected in step 1 was computed to obtain adjusted $R^{2}$ and model sum of squares corresponding to the fraction $\mathrm{S}+\mathrm{P}+\mathrm{SP}+\mathrm{BP}+\mathrm{BS}+\mathrm{BSP}$.

(5) A multiple regression model of proportion of forest cover against the subset of biophysical, socioeconomic, and programs variables selected in step 1 was computed to obtain adjusted $R^{2}$ and model sum of squares representing the total explained variation (i.e., $\mathrm{B}+\mathrm{S}+\mathrm{P}+\mathrm{BS}+$ $\mathrm{BP}+\mathrm{SP}+\mathrm{BSP})$.

To compute the $F$-statistics and test the significance of the estimated variation explained by a fraction $a$, the formula used was

$$
F_{[a]}=\frac{\mathrm{SS}_{[a]} / m}{\mathrm{SS}_{[d]} /(n-m-q-1)},
$$

where $m=$ number of variables in the explanatory data set(s) whose exclusive effect is being considered and $q=$ number of variables in the data set(s) whose effect is being controlled. The statistic is tested against the $F$-distribution with $m$ and $(n-m-q-1)$ degrees of freedom. Standardized partial regression coefficients and partial $r^{2}$ (Neter et al. 1996) were obtained to compare the relative magnitude of importance of individual variables within each explanatory data set. The regressions to obtain these coefficients for each set of explanatory variables were performed on residuals after the other two data sets were regressed on the proportion of forest. For example, to obtain the 
standardized regression coefficients and partial $r^{2}$ for the individual biophysical variables, socioeconomic and programs sets of variables were together regressed on proportion of a parcel covered with forest; the residuals were obtained and were used as the response to the biophysical set of variables.

\section{Results}

\section{General descriptive statistics}

Most privately-owned land was well drained (63\%) and $70 \%$ of the properties were underlain by loam soils. Over one third of the properties $(37 \%)$ fell mostly within designated floodplains and over half $(53 \%)$ could be considered prime farmland (Table 5). Parcels were located on both locally flat (minimum of 0.13 degrees average slope) and steep (maximum of 12.18 degrees average slope) areas, with a median of 2.61 degrees (Table 6).

Respondents owned between 0.34 and 219.41 ha $($ median $=11.78)$ and had owned their land for less than $1-60$ years $($ median $=14) \quad($ Table 5$)$. They generally owned their land for the lifestyle opportunities that it provided and as part of their family heritage or as a legacy for the future rather than for consumptive purposes such as timber production. Most respondents were male $(71 \%)$,

Table 5. Descriptive statistics for binary variables included in original data matrices.

\begin{tabular}{|c|c|c|}
\hline Matrix & Variable & Percentage of cases \\
\hline \multirow[t]{7}{*}{ Biophysical } & Well Drained & 63.01 \\
\hline & Poorly Drained & 31.05 \\
\hline & Alluvium/Shale & 16.44 \\
\hline & Loam/Drift & 70.32 \\
\hline & Floodplain & 37.44 \\
\hline & Prime Farmland & 53.42 \\
\hline & Not Prime Farmland & 9.13 \\
\hline \multirow[t]{11}{*}{ Socioeconomic } & Gender (male) & 71.36 \\
\hline & Farming Status (Farmer) & 20.19 \\
\hline & Politically Liberal & 11.00 \\
\hline & Politically Conservative & 44.98 \\
\hline & Education (post-secondary education) & 35.05 \\
\hline & Religiosity (attend services at least several times per year) & 59.41 \\
\hline & Income (annual household income $>\$ 74,999$ ) & 39.68 \\
\hline & Marital Status (Married) & 84.43 \\
\hline & Rural resident & 88.02 \\
\hline & Residency (Resident on parcel) & 86.11 \\
\hline & $\begin{array}{l}\text { Management (have previously planted trees beyond landscaping, } \\
\text { pre-commercially thinned, or harvested trees from their forest) }\end{array}$ & 65.73 \\
\hline Program & Classified Forest Program - (F) & 25.23 \\
\hline Familiarity (F) & Wildlife Habitat Program - (F) & 33.18 \\
\hline \multirow[t]{16}{*}{ and Enrollment (E) } & Conservation Reserve Program - $(\mathrm{F})$ & 41.78 \\
\hline & Forestry Incentives Program - $(\mathrm{F})$ & 13.62 \\
\hline & Stewardship Incentives Program - (F) & 8.41 \\
\hline & Wetland Reserve Program - (F) & 30.52 \\
\hline & Forest Land Enhancement Program - (F) & 7.94 \\
\hline & Wildlife Habitat Improvement Program - (F) & 16.82 \\
\hline & Certification - (F) & 11.21 \\
\hline & Easement - (F) & 13.55 \\
\hline & Land Trust $-(\mathrm{F})$ & 18.01 \\
\hline & Classified Forest Program - (E) & 4.67 \\
\hline & Wildlife Habitat Program - (E) & 3.74 \\
\hline & Conservation Reserve Program - (E) & 10.80 \\
\hline & Wetland Reserve Program - (E) & 2.82 \\
\hline & Certification - (E) & 0.47 \\
\hline & Easement - (E) & 1.87 \\
\hline & Land Trust $-(\mathrm{E})$ & 1.42 \\
\hline
\end{tabular}


Table 6. Descriptive statistics for continuous variables included in original data matrices.

\begin{tabular}{|c|c|c|c|c|}
\hline Matrix & Variable & Median & Minimum & Maximum \\
\hline \multirow[t]{2}{*}{ Biophysical } & Slope (degrees) & 2.61 & 0.13 & 12.18 \\
\hline & Depth of unconsolidated material (meters) & 33.8 & 7.6 & 110.7 \\
\hline \multirow[t]{7}{*}{ Socioeconomic } & Acreage (hectares) & 11.78 & 0.34 & 219.41 \\
\hline & Age (years) & 55 & 29 & 84 \\
\hline & Tenure (years) & 14 & 0 & 60 \\
\hline & Lifestyle (factor score) & 0.17 & -3.06 & 2.09 \\
\hline & Consumption (factor score) & -0.21 & -2.11 & 2.45 \\
\hline & Conservation (factor score) & 0.06 & -3.34 & 2.46 \\
\hline & Legacy and heritage (factor score) & 0.22 & -2.23 & 1.71 \\
\hline \multirow[t]{2}{*}{ Programs } & Familiarity index (number of programs) & 1 & 0 & 11 \\
\hline & Enrollment index (number of programs) & 0 & 0 & 4 \\
\hline
\end{tabular}

Table 7. Variables selected from the biophysical data matrix and used to compute a standardized regression model on residuals of percent forested area of parcels after socioeconomic and programs variables have been taken into account. ${ }^{a}$

\begin{tabular}{lcrl}
\hline Variable & $\begin{array}{l}\text { Standardized } \\
\text { regression coefficient }\end{array}$ & $p$-value & Partial $r^{2}$ \\
\hline Slope & 0.44 & $<0.0001$ & 0.18 \\
Loam/drift & -0.08 & 0.2207 & 0.01 \\
Floodplain & 0.04 & 0.6087 & 0.00 \\
\hline
\end{tabular}

${ }^{\mathrm{a}} p<0.0001 ; F=16.61(3,190 \mathrm{df})$.

married (84\%), politically conservative (45\%), religious $(59 \%)$ and did not self-identify as a farmer $(80 \%)$ (Table 6). Over one third earned household incomes of $\$ 75,000$ or more per annum and had attained some level of post-secondary education. The majority of respondents resided on their land, identified their residential surroundings as rural, and had previously engaged in some form of forest management. With regard to program familiarity and enrollment, the majority of respondents was neither familiar with nor enrolled in private landowner assistance programs. Familiarity ranged from under $10 \%$ for SIP and FLEP to over $40 \%$ for CRP. No landowners were enrolled in the FIP, SIP, FLEP, or WHIP. Among those programs in which landowners were enrolled, rates were quite low, ranging from less than $1 \%$ in certification programs to just below $11 \%$ in CRP.

\section{Models accounting for the variation}

Of the nine variables included in the biophysical data matrix, three were selected for inclusion in the final biophysical model (Table 7). Depth of unconsolidated material, drainage (well and
Table 8. Variables from the socioeconomic data matrix and used to compute a standardized regression model on residuals of percent forested area of parcels after biophysical and programs variables have been taken into account. ${ }^{a}$

\begin{tabular}{lccl}
\hline Variable & $\begin{array}{l}\text { Standardized } \\
\text { regression coefficient }\end{array}$ & $p$-Value & Partial $r^{2}$ \\
\hline Lifestyle & 0.20 & 0.0067 & 0.04 \\
Acreage & -0.18 & 0.0162 & 0.03 \\
Married & 0.15 & 0.0342 & 0.02 \\
Farmer & -0.07 & 0.3683 & 0.00 \\
Management & 0.05 & 0.4402 & 0.00 \\
\hline
\end{tabular}

${ }^{\mathrm{a}} p<0.0001 ; F=5.69$ (5,188 df).

poorly), alluvium/shale surficial geology type, and farmland status (prime and not prime) did not meet the criteria for inclusion in the model. After removing the variation accounted for by socioeconomic and programs variables, slope was the only significant biophysical variable $(p<0.0001)$ and associated positively with the proportion of land in forest, with a partial $r^{2}$ of 0.18 . Slope also had the single highest partial $r^{2}$ of all variables included in this study.

Five socioeconomic variables out of 22 were selected in the final model of which three remained significant after accounting for variation attributable to biophysical factors and programs. Age, tenure, three ownership motivations (consumption, conservation, and legacy and heritage), gender, political ideology (liberal and conservative), education, religiosity, income, rural resident status, and residency did not meet the criteria for inclusion in the model. In order of decreasing standardized regression coefficient, the significant variables were lifestyle $(p=0.0067)$, acreage $(0.0162)$, and marital status $(p=0.0342)$ (Table 8$)$. The lifestyle 
Table 9. Variables selected from the programs data matrix and used to compute a standardized regression model on residuals of percent forested area of parcels after biophysical and socioeconomic variables have been taken into account. ${ }^{a}$

\begin{tabular}{|c|c|c|c|}
\hline Variable & Standardized Regression Coefficient & $p$-value & Partial $r^{2}$ \\
\hline Index of familiarity & 0.49 & 0.0220 & 0.03 \\
\hline Easement & -0.30 & 0.0091 & 0.04 \\
\hline Forestry Incentives Program & -0.20 & 0.0796 & 0.02 \\
\hline Wetland Reserve Program & -0.10 & 0.3496 & 0.00 \\
\hline Conservation Reserve Program & -0.10 & 0.3659 & 0.00 \\
\hline
\end{tabular}

${ }^{\mathrm{a}} p=0.1418 ; F=1.68(5,188)$; All variables relate to familiarity with programs rather than enrollment.

Table 10. Variation in parcel forested explained exclusively by biophysical, socioeconomic, and conservation programs and in combination, with associated test statistics ${ }^{\mathrm{a}}$.

\begin{tabular}{lcrrr}
\hline Data matrix or matrices & Variation explained (\%) & $F$-statistic & df & $p$-Value \\
\hline Biophysical, Socioeconomic, \& Programs & 48.50 & 14.98 & 13,180 & $<0.0001$ \\
Biophysical & 17.35 & 21.19 & 3,177 & $<0.0001$ \\
Socioeconomic & 7.97 & 6.54 & 5,175 & $<0.0001$ \\
Programs & 0.90 & 1.60 & 5,175 & 0.1636 \\
Biophysical \& Socioeconomic & 42.63 & 19.54 & 8,172 & $<0.0001$ \\
Socioeconomic \& Programs & 9.96 & 4.41 & 10,170 & $<0.0001$ \\
Biophysical \& Programs & 19.36 & 9.39 & 8,172 & $<0.0001$ \\
\hline
\end{tabular}

${ }^{\mathrm{a}}$ Refer to Figure 2 for decomposed variations.

ownership motivation and marital status were positively associated with forest cover while acreage was negatively associated. Married landowners had an average of $61.1 \%$ forest (CL 57.0, 65.2; $n=179$ ) compared to unmarried landowners who owned property with an average of $45.7 \%$ forest cover (CL 36.3, 55.1; $n=33$ ).

Of the 18 variables originally included in the programs matrix, 5 were selected in the final model, none of which were enrollment variables. After accounting for the variation explained by biophysical and socioeconomic factors, the index of program familiarity $(p=0.0220)$ and familiarity with easements $(p=0.0091)$ were significant (Table 9). Landowners who indicated familiarity with easements had an average of 48.2\% (CL 37.4, $59.5 ; n=29$ ) forest cover on their parcels compared to $60.1 \%$ (CL 56.0, 64.1; $n=185$ ) for those who were not familiar.

\section{Variation partitioning}

The three data matrices together explained $48.5 \%$ of the variation $(p<0.0001)$ in the proportion of private land that was covered in forest (Table 10, Figure 2). Of the three matrices, biophysical attributes explained the greatest amount of unique var- iation $(17.35 \%, p<0.0001)$ with an additional $7.97 \%$ of the variation explained uniquely by socioeconomic attributes $(p<0.0001)$. Program familiarity and enrollment did not explain a significant amount of the variation independent of either biophysical or landowner attributes $(p=0.1636)$. When the three data matrices were paired, each pair explained a significant amount of variation. Biophysical and socioeconomic factors had considerable intersection and together explained $42.63 \%$, accounting for $87.90 \%$ of the variation explained overall.

\section{Discussion}

The observation that biophysical characteristics of the landscape, slope in particular, influence the local abundance of forest cover in agricultural landscapes has been previously reported for many areas of the Midwestern USA (e.g., Auclair 1976; Iverson 1998; Scull and Harman 2004). It is clear from this study that the contributions of attitudes and demographic characteristics of the landowners themselves to maintenance of forest cover on private ownerships across the landscape cannot be overlooked. This finding is particularly important 


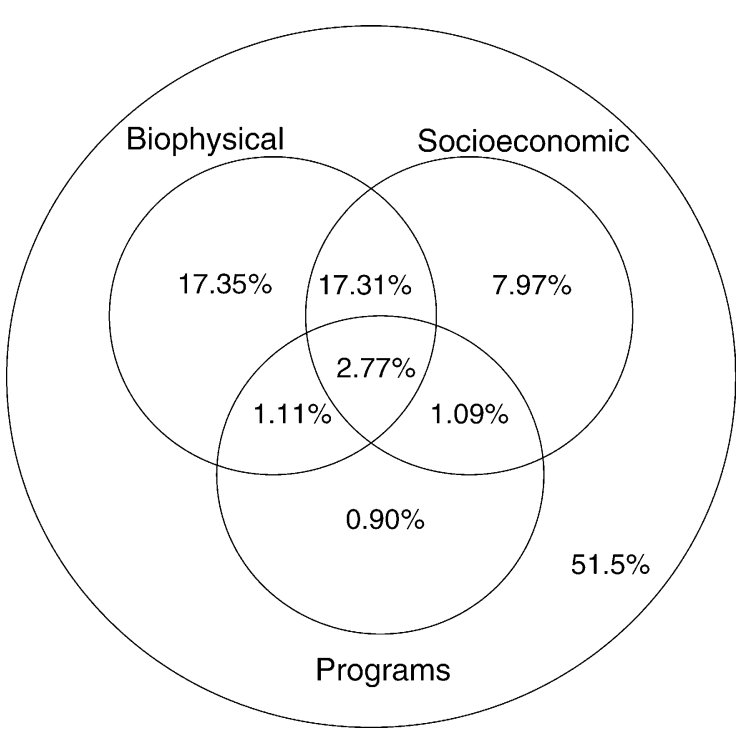

Figure 2. Venn diagram illustrating the contributions of the three data matrices in explaining the variation in the proportion of forest cover on privately owned land in north-central Indiana, USA. Refer to Table 10 for statistics. Note: $51.5 \%$ represents the variation that remains unexplained by the full model (i.e., $100-48.5 \%$ ).

given the increased diversity of family forest owners as a result of exurbanization, for example, and the numerous changes to the expectations held by these constituents of professional natural resource agencies that result from this increased diversity (Hull et al. 2004). Independent of the biophysical characteristics of the land, forest cover was higher on smaller parcels, and on those properties owned by those who were married and valued their forest for the lifestyle opportunities it provided (e.g. privacy). The large overlap in the variation explained by biophysical and socioeconomic factors suggests that most people who desire to reside on forested parcels buy land that is already forested, which happens to be in agriculturally-inferior areas, as opposed to purchasing deforested land and investing the time and money into afforestation or reforestation.

The many private landowner assistance programs aimed at conservation did not appear to have an effect on forest cover independent of either the biophysical characteristics of the land or attributes of the landowners. There is clearly room for improvement with regard to the efficacy of programs in conserving forest on privately-owned lands as many landowners are not enrolled in or even aware of these programs. Further, programs did not independently account for forest cover in the north-central Indiana landscape, suggesting that the distribution of such cover primarily reflects biophysical characteristics and landowner motivations, not program incentives. Forest cover on private property in this agriculturally-dominated landscape may be increased through, for example, a concerted effort to encourage farmers and those who own larger acreages to diversify their enterprises via active forest management (e.g., market solutions as discussed in Best and Wayburn 2001).

It may also be insightful to consider the implications of program enrollment criteria (e.g., minimum acreage requirements) in the face of decreasing forest patch sizes due to parcelization. Given our average parcel size of 2.23 ha $(5.51 \mathrm{ac})$, most landowners in our study area would not qualify for enrollment in the Classified Forest Program which requires a minimum of 4.05 ha (10 ac) of contiguous forest to participate. An analysis of the property-level distribution of forest blocks in our study area showed that in spite of the fragmentation, including 'artificial' fragmentation imposed by property boundaries, removing the contiguity condition does not increase the number of landowners who qualify for enrollment. Only by lowering the minimum acreage requirement would more landowners be eligible to participate. An alternative or complementary modification for eligibility might be to also allow neighboring landowners to jointly enroll contiguous forest that is dissected by property boundaries, which would in effect allow for the protection of more contiguous forest across the landscape.

Although it is counterintuitive that familiarity with specific programs was associated with lower abundance of forest, it is actually not surprising given that many landowner assistance programs target members of the farming community who are seeking to better the environmental conditions of their land. It is worth noting that, by no means, do we infer from our results that familiarity with private landowner assistance programs causes a loss of forest cover on private property. Rather, our results suggest that forest cover is lower among those landowners who are familiar with a particular program but higher among those familiar with the suite of programs available to them.

Targeting landowners with particular socioeconomic characteristics could be an effective means 
to increase the abundance of forest cover on private ownerships, but will be difficult as most socioeconomic information is not publicly available and must be acquired through personal contact. This may be very time consuming and will likely be perceived as intrusive by the landowners. It should, however, be possible and acceptable to target landowners whose properties are located on agriculturally-inferior or marginal lands, especially steep slopes, through the use of GIS. A similar policy of recovering marginal lands was encouraged in Illinois (Iverson 1988). The downside of this approach is that it perpetuates the existing pattern of concentrating forest cover on poorquality agricultural soils. Scull and Harman (2004) argued that continuing to encourage growth of forest on sites that are already over-represented (as compared to other site types, not as compared to historical forest cover) with forest may not be good conservation policy. They suggested that policy aimed at increasing the potential biodiversity of an area include provisions that encourage redevelopment of native habitat on those sites no longer supporting their equal share of forest cover such as high quality soils that are typically used for agricultural production. This skewed distribution of the occurrence of forest cover on marginallyproductive soils may not necessarily be a problem if reforestation is being encouraged primarily for watershed and stream protection. Steep slopes tend to be associated with riparian lands, which are the target for most watershed and stream habitat protection programs. The economic implication of encouraging conversion of some productive agricultural lands to forest is that society should be willing to increase incentives (or pay higher compensation to farmers) through conservation programs, with price differentials determined by site biophysical characteristics. It is also important to realize that farming, just like creating and keeping forest cover as identified in our study, is a way of life and family tradition for many landowners (Medley et al. 1995; Kendra and Hull 2005). Thus, paying a higher price for land may be a necessary but insufficient condition to convince some landowners to convert a portion of their agricultural land to forest cover. For such landowners, willingness to pay and willingness to accept will diverge significantly. For a few, willingness to accept may actually be unthinkable.

\section{Conclusion}

This study found that current abundance of forest cover on private lands in north-central Indiana is accounted for almost exclusively by biophysical attributes of the land and landowner socioeconomic characteristics. Low program enrollment and the lack of influence of program familiarity and enrollment on the relative abundance of forest cover on privately-owned land leads us to speculate that current programs do not effectively encourage the conversion to or maintenance of forest on private ownerships. Policy design and implementation should respond to the decreasing size of the average parcel as well as the diversity of landowners' ownership objectives and management goals and target those sites that are severely underrepresented in terms of forest cover (e.g., rich soils and plains) through increased incentives.

\section{Acknowledgements}

We would like to thank Dr. Bernie Engel, Department of Agricultural and Biological Engineering (ABE), Purdue University, for granting us unlimited access to ABE spatial databases. Kenli Schaaf, Graduate Research Assistant, Purdue University, provided invaluable feedback on an earlier draft of the manuscript. Funding for this research was provided by the Departments of Forestry and Natural Resources and Agricultural Economics through the Initiative for Future Agricultural and Food Systems (IFAFS) project.

\section{References}

Alig R.J., Lee K.J. and Moulton R.J. 1990. Likelihood of timber management on nonindustrial private forests: evidence from research studies. USDA Forest Service General Technical Report SE-60.

Anderson M.J. and Gribble A.N. 1998. Partitioning the variation among spatial, temporal and environmental components of a multivariate data set. Aust. J. Ecol. 23: 158-167.

Auclair A.N. 1976. Ecological factors in the development of intensive-management ecosystems in the Midwestern United States. Ecology 57: 431-444.

Beach R.H., Pattanayak S.K., Yang J-C., Murray B.C. and Abt R.C. 2005. Econometric studies of non-industrial private forest management: A review and synthesis. Forest Policy Econ. 7: 261-281. 
Bernardin, Lochmueller et al., 2002. Floodplains in Indiana (1:633,600 polygon shapefile). In: Douglas Clark G. (ed.), The Indiana Water Resource: Availability, Uses, and Needs. Bernardin, Lochmueller and Associates, Evansville, Indiana.

Best C. and Wayburn L.A. 2001. America's Private Forests: Status and Stewardship. Island Press, Washington pp. 268

Birch T.W. 1996. Private-forest land owners of the United States, 1994. United States Department of Agriculture, Forest Service, Northeastern Forest Experiment Station, Resource Bulletin NE-134. USDA Forest Service, Radnor, Pennsylvania.

Brown D.G. 2003. Land use and forest cover on private parcels in Upper Midwest, USA, 1970 to 1990. Landscape Ecol. 18: 777-790.

Burgi M. and Turner M.G. 2002. Factors and processes shaping land cover and land cover changes along the Wisconsin River. Ecosystems 5: 184-201.

Butler B.J. and Leatherberry E.C. 2004. America's family forest owners. J. Forest. 102: 4-9.

Dillman D. 2000. Mail and Internet Surveys: The Tailored Design Method 2nd ed. John Wiley \& Sons, Inc., New York, USA.

Egan A.F. and Luloff A.E. 2000. The exurbanization of American's forests: Research in rural social science. J. Forest. 98: 26-30.

Erickson D.L., Ryan R.L. and De Young R. 2002. Woodlots in the rural landscape: Landowner motivations and management attitudes in a Michigan (USA) case study. Landsc. Urban Plan. 58: 101-112.

Franzmeier D.P., Steinhardt G.C. and Lee B.D. 2001. Indiana soils: evaluation and conservation. Purdue University Cooperative Extension Service Publication ID-72, pp. 7-01

Frissell C.A. and Bayles D. 1996. Ecosystem management and the conservation of aquatic biodiversity and ecological integrity. Water Resour. Bull. 32: 229-240.

Guber D.L. 2003. The Grassroots of a Green Revolution: Polling American on the Environment. MIT Press, Cambridge, pp. 279

Hull B.R., Robertson D.P and Buhyoff G.J. 2004. "Boutique" forestry: New forest practices in urbanizing landscapes. J. Forest. 102: 14-19.

Indiana Geological Survey 2002a. Quaternary geologic map of Indiana (Indiana Geological Survey, 1:500,000, Polygon Shapefile). Indiana Geological Survey, Bloomington, IN.

Indiana Geological Survey 2002b. Thickness ranges of unconsolidated deposits in Indiana (Indiana Geological Survey, 1:500,000, Polygon Shapefile). Indiana Geological Survey, Bloomington, IN.

Iverson L.R. 1988. Land-use changes in Illinois, USA: The influence of landscape attributes on current and historic land use. Landscape Ecol. 2: 45-61.

Jones R.E. and Dunlap R.E. 1992. The social bases of environmental concern: have they changed over time? Rural Sociol. 57: 28-47.

Kanagy C.L. and Nelsen H.M. 1995. Religion and environmental concern: challenging the dominant assumptions. Rev. Relig. Res. 37: 33-45.

Kendra A. and Hull R.B. 2005. Motivations and behaviors of new forest owners in Virginia. Forest Sci. 51: 142-154.

Lengendre P. and Legendre L. 1998. Developments in Numerical Ecology (NATO ASI Series, Series G: Ecological Sciences, Volume 14). Springer, New York, USA.
Lidestav G. and Ekström M. 2000. Introducing gender in studies on management behaviour among non-industrial private forest owners. Scand. J. Forest Res. 15: 378-386.

Lönnstedt L. 1997. Nonindustrial private forest owners' decision process: A qualitative study about goals, time perspective, opportunity, and alternatives. Scand. J. Forest Res. 12: 302-310.

Loyland K., Ringstad V. and Oy H. 1995. Determinants of forest activities - A study of private nonindustrial forestry in Norway. J. Forest Econ. 1: 219-237.

Magalhaes M.F., Batalha D.C. and Collares-Pereira M.J. 2002. Gradients in stream fish assemblages across a Mediterranean landscape: contributions of environmental and spatial structure. Freshw. Biol. 47: 1015-1031.

Mallow C.L. 1964. Choosing Variables in a Linear Regression: A Graphical Aid. Presented at the Central Regional Meeting of the Institute of Mathematical Statistics, Manhattan, Kansas.

Marsh P.C. and Luey J.E. 1982. Oases for aquatic life within agricultural watersheds. Fisheries 7: 16-24.

Medley K.E., Okey B.W., Barrett G.W., Lucas M.F. and Renwick W.H. 1995. Landscape change with agricultural intensification in a rural watershed, southwestern Ohio, USA. Landscape Ecol. 10: 161-176.

Moore J.E. and Swihart R.K. 2005. Modeling patch occupancy by forest rodents: Incorporating detectability and spatial autocorrelation with hierarchically structured data. Journal of Wildlife Management. 69(3): 933-949.

Natural Resources Conservation Service 1994. State Soil Geographic (STATSGO) database for Indiana $(1: 250,000)$. US Department of Agriculture, NRCS, Fort Worth, Texas.

Neter J., Kutner M.H., Nachtsheim C.J. and Wasserman W. 1996. Applied Linear Statistical Models, 4th ed.. McGrawHill, New York, USA.

Norušis M.J. 2003. SPSS 12.0 Statistical Procedures Companion. Prentice Hall, Upper Saddle River, NJ, USA.

Odum W.E. 1982. Environmental degradation and the tyranny of small decisions. BioScience 32: 728-729.

Omernik J.M. 1987. Ecoregions of the conterminous United States. Ann. Assoc. Am. Geogr. 77: 118-125.

Pan D., Domon G., de Blois S. and Bouchard A. 1998. Temporal (1958-1993) and spatial patterns of land use changes in Haunt-Saint-Laurent (Quebec, Canada) and their relation to landscape physical attributes. Landscape Ecol. 14: 35-52.

Royer J.P. and Moulton R.J. 1987. Reforestation incentives: Tax incentives and cost sharing in the south. J. Forest. 85: 45-47.

Scull P.R. and Harman J.R. 2004. Forest distribution and site quality in southern Lower Michigan, USA. J. Biogeogr. 31: 1503-1514.

Turner W.M. 1997. Achieving private-sector involvement and its implications for resource professionals. In: William J.E., Wood C.A. and Dombeck M.P. (eds), Watershed Restoration: Principles and Practices. American Fisheries Society, Bethesda, MD, USA, pp. 158-176.

United States Census Bureau 2005. State and County Quickfacts. [online] URL: http://quickfacts.census.gov/qfd/ Accessed October 16, 2005.

United States Department of Agriculture (USDA), National Agriculture Statistics Service (NASS) 2005. Cropland data layer (USDA, NASS, 1:100,000, Grid). USDA-NASS Marketing Division, Washington, DC. 
United States Geological Survey 2004. National elevation data set. USGS, Sioux Falls, South Dakota.

Van Liere K.D. and Dunlap R.E. 1980. The social bases of environmental concern: a review of hypotheses, explanation, and empirical evidence. Public Opin. Q. 44: 181-197.
Whittaker J. 1984. Model interpretation form the additive elements of the likelihood function. Appl. Stat. 33: 52-64.

Zhang D. and Flick W.A. 2001. Sticks, Carrots, and reforestation investment. Land Econ. 77: 443-456. 